\title{
Influence Of Deicing Chemicals Contaminating Automobile Headlamps On Light Intensity
}

\author{
Fedotov Aleksandr I., doctor of technical Sciences \\ Department "Automobile transport" \\ Irkutsk national research technical University \\ 664074, Irkutsk, Lermontov str., 83 \\ e-mail: fai@istu.edu
}

\author{
Kornyakov Mikhail V., doctor of technical Sciences \\ Rector \\ Irkutsk national research technical University \\ 664074, Irkutsk, Lermontov str., 83 \\ e-mail: rector@istu.edu
}

\author{
Gromalova Viktoriya O., postgraduate student of the \\ Department "Automobile transport" \\ Irkutsk national research technical University \\ 664074, Irkutsk, Lermontov str., 83 \\ e-mail: gromalova@mail.ru
}

Gergenov Sergei M., candidate of technical Sciences
East Siberian state University of technologies and
management
670013, Republic Buryatiya, Ulan-Ude, Klyuchevskaya str., $40 \mathrm{~V}$

e-mail: gergenovsm@gmail.com

\begin{abstract}
The paper aims to identify the influence of deicing chemical contaminating automobile headlamps on light intensity in wintertime. Methods. Researches on the influence of deicing chemical contaminating automobile headlamps on light intensity were analyzed. Experiments on automobile lights contamination in wintertime were conducted under real road conditions. Variation in lights intensity due to contamination by deicing chemicals was studied. Results and discussion. Experimental methods for studying the influence of contaminated automobile headlamp beam transmission during the continuous automobile operation on the headlamp intensity were developed and approved. The experimental results are presented in tables, diagrams and graphs. Conclusions. The authors found that on winter roads covered with deicing chemicals, external automobile lights, including headlamps are contaminated. New data on the influence of headlamp contamination by deicing chemicals on light intensity at night were obtained. The experimental results were verified by curves which can be used for studying the influence of automobile headlamp contamination on light intensity in wintertime.
\end{abstract}

Keywords - light transmission, light intensity, deicing chemicals, contamination of external automobile lights, winter road slipperiness.

\section{INTRODUCTION}

Automobile is the most dangerous vehicle. Every year about 25 thousand people die in road crashes and more than 250 thousand people get injured.

The issue of automobile safety in wintertime is still crucial. According to the statistical data of the State Road Safety Inspection for 2017, in Irkutsk oblast, the number of automobile pedestrian accidents in pedestrian crossing areas increased by 3,3\% compared with the same period in 2016 [3]. According to the statistical data of the State Road Safety
Inspection, from the fourth quarter of 2016 to the first quarter of 2017, there were 643 road accidents in Irkutsk oblast. 671 persons got injured, 274 of them - in pedestrian crossing areas (103 of them - at night). Every third road accident happens at night. Every second road accident casualty dies at night because of poor visibility.

Winter slipperiness is typical of many Russian regions. The duration of this period is 5-6 months. Snow and ice deposit formation time is from 2 to 2,4 months.

The Road winter slipperiness guidance [1] distinguishes between three types of snow and ice road deposits: soft snow, packed snow and glass-like snow. All these snow and ice deposits (SIDs) have to be eliminated when required [1]. One of the most widespread elimination methods is application of deicing agents (DAs) [1].

DAs can be chemical, frictional or combined [2]. If natural components (mixtures of sand, gravel, stone) are part of frictional materials, chemical DAs consist of hard salts (technical sodium chloride, sylvanite waste salt, calcium chloride) [2].

\section{METHODS AND EXPERIMENT RESULTS}

Many modern researches deal with the DA influence on road safety and automobile performance characteristics [5], $[6],[7],[8]$.

Analysis of researches shows that most of them do not take into account a significant negative aspect of the DA influence on road safety: on winter roads, chemical deicing agents are miscible with precipitation contaminating car bodies, external lights, windows, outside rearview mirrors, etc. (Fig. 1,2). 


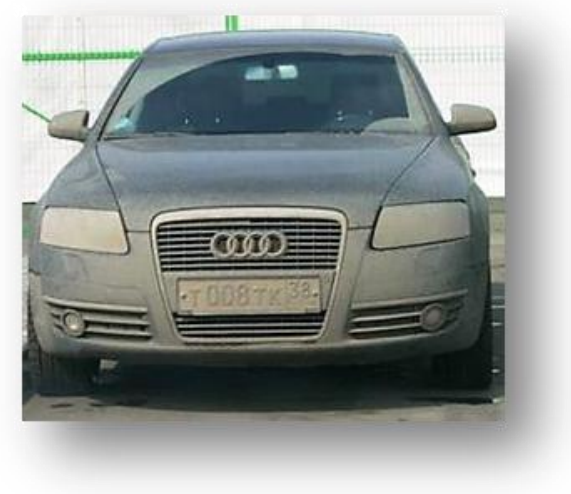

Fig. 1. A car with contaminated external lights in wintertime

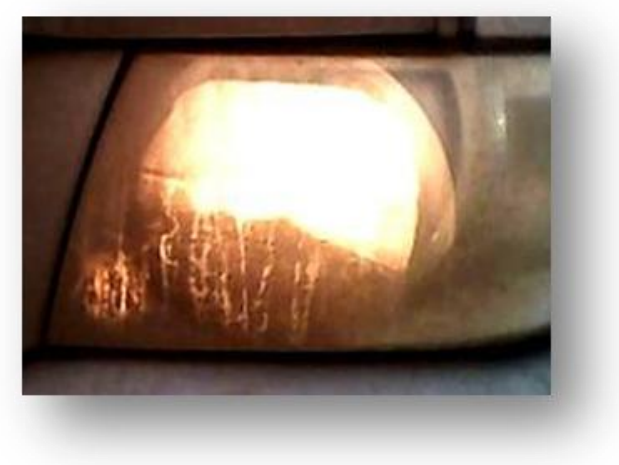

Fig. 2. A Nissan headlamp contaminated by DAs in wintertime

External lights of a car moving along winter roads and streets covered with deicing agents become contaminated. It decreases intensity of external lights at night obstructing the driver's view. Good illumination of the road infrastructure at night is an important factor of road safety on slippery winter roads.

The influence of automobile lights contaminated by deicing agents on lights intensity has never been studied. The study could identify the effects of deicing agents on lights surface contamination, develop measures for reducing the negative influence on winter road safety at night.

Before carrying out the experiment under real conditions of winter roads covered with deicing agents, Toyota Fun Cargo (Fig. 3) was prepared as follows:

1. New headlamps meeting European requirements were set; high and low beam headlamps were adjusted according to the Technical Wheeled Vehicle Safety Regulations of the Customs Union CU TR018/2011 (§ 3.8.4) [11].

2. To measure intensity of contaminated headlamps, transparent screens for both headlamps were prepared and installed (Fig. 4);

3. A pattern for fast identification of check zones at nine equally-spaced headlamps screen surface contamination checkpoints was developed;

4. Two persons were trained for carrying out the experiment.
5. The experiment methods were developed.

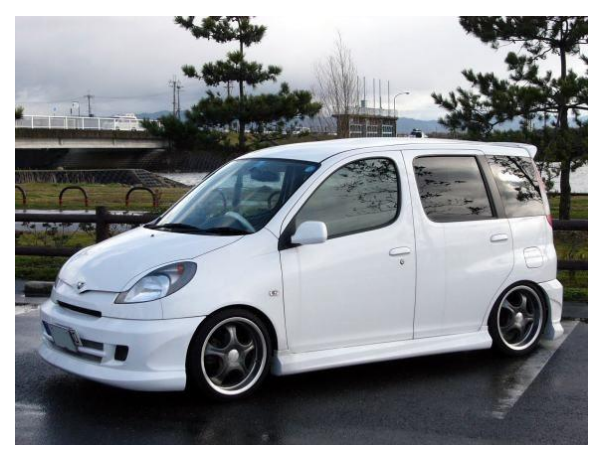

Fig. 3 Test Toyota Fun Gargo

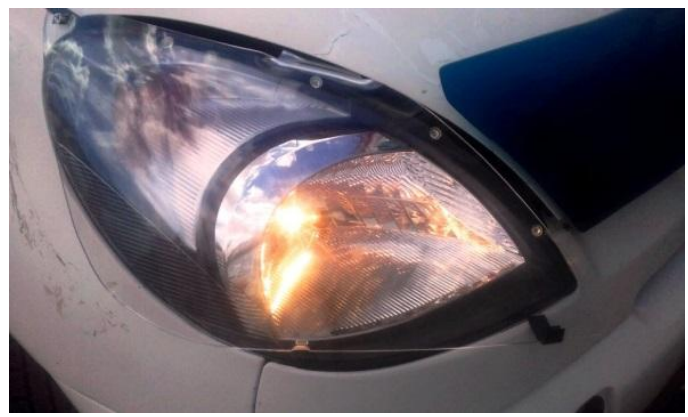

Fig. 4 Transparent headlamp screen

A number of external factors influence the contamination by deicing agents under real road conditions. Therefore, the number and duration of tests were identified for carrying out experimental studies.

Experimental studies on headlamps contamination by deicing agents were carried out in winter under the following road and climatic conditions: average air temperature varied from $-23^{0} \mathrm{C}$ to $+1^{0} \mathrm{C}$ (as far as roads get slippery within this temperature range); snow precipitation; use of deicing agents on roads.

External lights contamination by deicing agents was assessed by measuring light transmission using a light transmission gage TONIK (Fig. 5) [12].

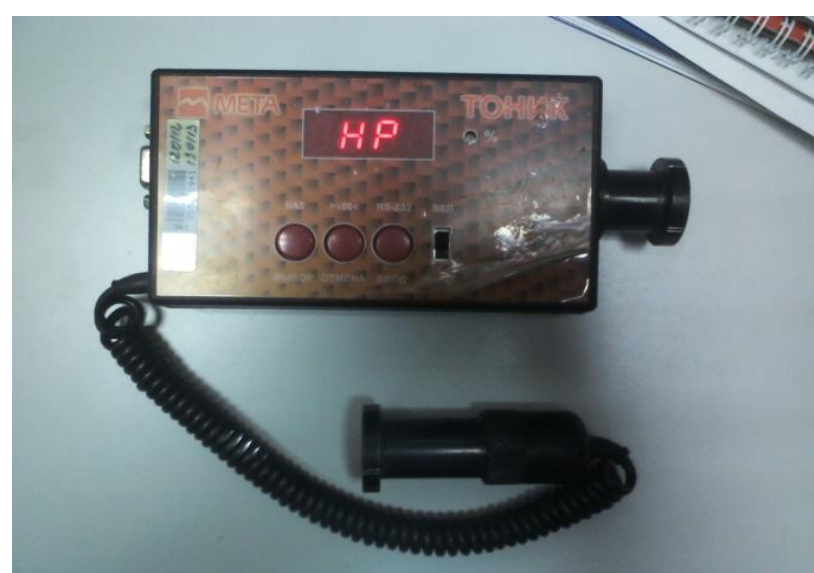

Fig. 5. Light transmission gage TONIK

At the first stage of the experiment, initial light 
transmission for clean and transparent headlamp screens was measured.

Headlamp screen light transmission was measured in the following sequence:

- A pattern for identifying transmission control zones at nine equally-spaced points was installed on the inner side of the transparent headlamp screen;

- Light transmission of left and right headlamp screens was measured at each point;

- Average light transmission values were determined;

- Transparent screen transmission measurement results were tabulated (Table 1).

- Then the screens were installed on Toyota FunCargo's headlamps.

The experimental studies on the influence of external lights contamination by deicing agents on light intensity consisted of the following stages:

1. The car ran at the distance of $100 \mathrm{~km}$ on Irkutsk roads covered with deicing agents under the following road and climatic conditions:

- air temperature varied from $-20^{0} \mathrm{C}$ to $+4^{0} \mathrm{C}$;

- air pressure varied from 84 to $106,7 \mathrm{kPa}$;

- relative humidity was $95 \%$ at $30^{\circ} \mathrm{C}$;

2. Contaminated headlamp screens were removed;

3. Transmission of each screen was measured at nine checkpoints (according to the method described above);

4. Arithmetical mean values of transmission measurement results at nine screen checkpoints were calculated;

5. Experiment results were tabulated (see Table 1).

TABLE I. TRANSPARENT SCREEN TRANSMISSION MEASUREMENT RESULTS

\begin{tabular}{|c|c|c|c|c|c|c|}
\hline \multirow{3}{*}{$\begin{array}{l}\text { No of the } \\
\text { experiment } \\
\text { and its } \\
\text { parameters }\end{array}$} & \multicolumn{6}{|c|}{ Recordings of the gage TONIK, $\%$} \\
\hline & \multicolumn{3}{|c|}{ Right headlamp } & \multicolumn{3}{|c|}{ Left headlamp } \\
\hline & \multicolumn{2}{|c|}{$\begin{array}{c}\text { At } \\
\text { checkpoint } \\
\text { s }\end{array}$} & Mean & \multicolumn{2}{|c|}{$\begin{array}{c}\text { At } \\
\text { checkpoint } \\
\text { s }\end{array}$} & Mean \\
\hline \multirow{9}{*}{$\begin{array}{c}1 \\
\text { (clean } \\
\text { screen) }\end{array}$} & 1 & 99 & 98,3 & 1 & 96,6 & 96,6 \\
\hline & 2 & 97,1 & & 2 & 96,6 & \\
\hline & 3 & 97,4 & & 3 & 98,7 & \\
\hline & 4 & 99,7 & & 4 & 97,6 & \\
\hline & 5 & 97,7 & & 5 & 95,4 & \\
\hline & 6 & 100 & & 6 & 98,5 & \\
\hline & 7 & 100 & & 7 & 93,8 & \\
\hline & 8 & 95,6 & & 8 & 93,8 & \\
\hline & 9 & 98,5 & & 9 & 99,2 & \\
\hline \multirow{2}{*}{$\begin{array}{c}2 \\
\text { (after the }\end{array}$} & 1 & 83,4 & 84,84 & 1 & 84,3 & 84,24 \\
\hline & 2 & 85,7 & & 2 & 84,8 & \\
\hline
\end{tabular}

\begin{tabular}{|c|c|c|c|c|c|c|}
\hline \multirow{9}{*}{$\begin{array}{l}\text { No of the } \\
\text { experiment } \\
\text { first set of } \\
\text { test runs) }\end{array}$} & \multicolumn{6}{|c|}{ Recordings of the gage TONIK, $\%$} \\
\hline & \multicolumn{3}{|c|}{ Right headlamp } & \multicolumn{3}{|c|}{ Left headlamp } \\
\hline & 3 & 85,1 & & 3 & 84,5 & \\
\hline & 4 & 86,9 & & 4 & 87,9 & \\
\hline & 5 & 90,2 & & 5 & 84,8 & \\
\hline & 6 & 87,9 & & 6 & 84,8 & \\
\hline & 7 & 86,8 & & 7 & 75,5 & \\
\hline & 8 & 70 & & 8 & 89,5 & \\
\hline & 9 & 87,6 & & 9 & 82,1 & \\
\hline \multirow{9}{*}{$\begin{array}{c}3 \\
\text { (after the } \\
\text { second set } \\
\text { of test runs) }\end{array}$} & 1 & 43,4 & 54,8 & 1 & 41,2 & 55 \\
\hline & 2 & 59 & & 2 & 46,3 & \\
\hline & 3 & 61 & & 3 & 54,7 & \\
\hline & 4 & 54,1 & & 4 & 44,1 & \\
\hline & 5 & 44,6 & & 5 & 52,4 & \\
\hline & 6 & 57,5 & & 6 & 65,5 & \\
\hline & 7 & 56,1 & & 7 & 53,7 & \\
\hline & 8 & 42,8 & & 8 & 59,2 & \\
\hline & 9 & 74,8 & & 9 & 78,1 & \\
\hline \multirow{9}{*}{$\begin{array}{c}4 \\
\text { (after the } \\
\text { third set of } \\
\text { test runs) }\end{array}$} & 1 & 9,7 & 21,8 & 1 & 8,5 & 11,5 \\
\hline & 2 & 12,5 & & 2 & 7,8 & \\
\hline & 3 & 12,7 & & 3 & 6,4 & \\
\hline & 4 & 8,9 & & 4 & 9,4 & \\
\hline & 5 & 11,3 & & 5 & 7,4 & \\
\hline & 6 & 18,6 & & 6 & 8,4 & \\
\hline & 7 & 48 & & 7 & 19 & \\
\hline & 8 & 36 & & 8 & 28 & \\
\hline & 9 & 39 & & 9 & 8,8 & \\
\hline
\end{tabular}

Identification of required sets of test runs for analysis of external lights contamination in wintertime depended on weather and road conditions.

Then, the data in Table 1 were processed in Microsoft Excel and graphs were constructed (Fig. 6).

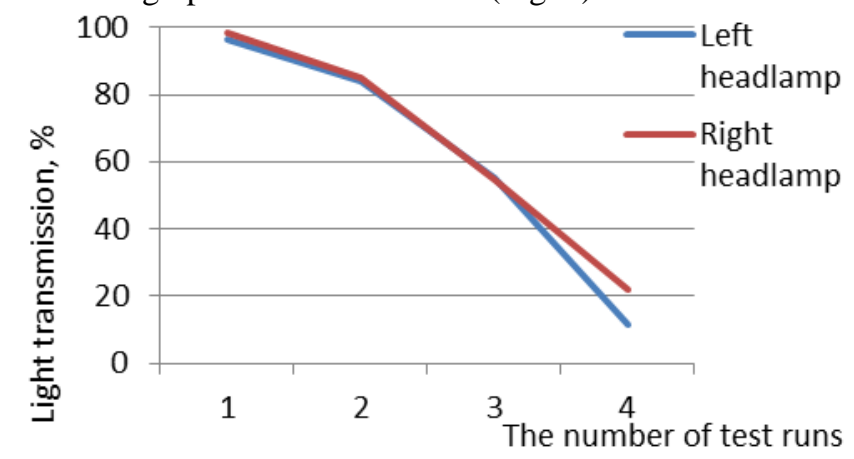

Fig. 6 Light transmission curve for Toyota FunCargo's headlamp screens contaminated by salt deicing agents on Irkutsk roads in March-April 2018 at temperatures varying from $-23 \mathrm{oC}$ to $-1 \mathrm{oC}$. 
After each set of test runs, light intensity and light transmission were measured. Measurements were carried out for high and low beam headlamps contaminated by deicing agents using IPF-01 (Fig.7) on a special flat horizontal platform.
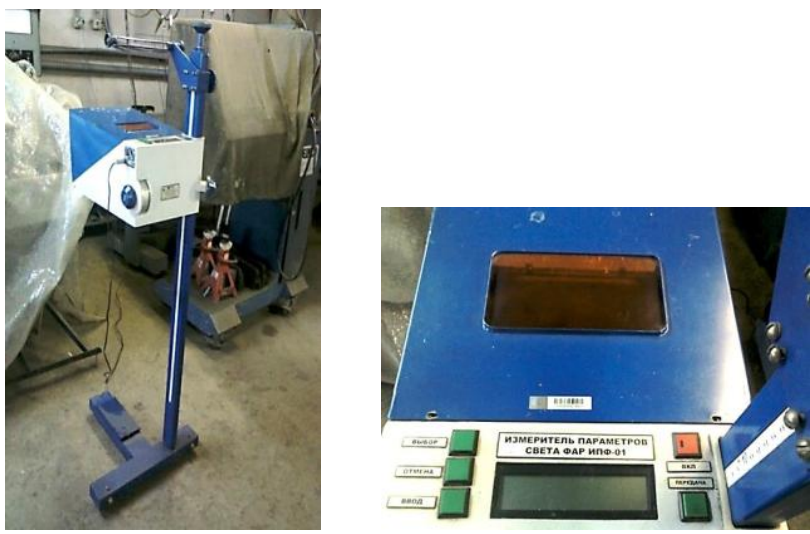

Fig. 7 Headlamp illumination gage IPF-01

Light intensity was measured according to the recommendations of the IPF-01 manual:

- The automobile was on a flat horizontal platform;

- Tire pressure was measured according to Table 2. If required, pressure was optimized;

TABLE 2. THE NORMAL TIRE PRESSURE OF THE VEHICLE TOYOTA Fun CARGO

\begin{tabular}{|c|c|c|c|}
\hline $\begin{array}{c}\text { Automobile } \\
\text { model }\end{array}$ & Tire size & $\begin{array}{c}\text { Front tire } \\
\text { pressure } \\
\text { (MPa / } \\
\text { Bar) }\end{array}$ & $\begin{array}{c}\text { Rear tire } \\
\text { pressure } \\
(\mathrm{MPa} / \\
\mathrm{Bar})\end{array}$ \\
\hline $\begin{array}{c}\text { Toyota Fun } \\
\text { Cargo }\end{array}$ & $185 / 65 / \mathrm{R} 14$ & $0,22 / 2,2$ & $0,22 / 2,2$ \\
\hline
\end{tabular}

- Low and high beam headlamps were adjusted according to $\S 3.8 .4$. of the Technical Wheeled Vehicles Safety Regulations of the Customs Union CU TR018/2011 [11].;

- Screens were installed on the automobile headlamps (before and after each test run);

- Light intensity of the right and left low beam headlamps was measured along the optical headlamp axis;

- Measurement results for right and left low beam headlamps intensity were tabulated (Table 3 ).

- Light intensity was measured for the right and left high beam headlamps;

- Measurement results for right and left high beam headlamps intensity were tabulated (Table 3 ).
TABLE 3 . MEASUREMENT RESULTS FOR RIGHT AND LEFT HEADLAMPS INTENSITY

\begin{tabular}{|c|c|c|c|c|c|}
\hline \multirow{3}{*}{$\begin{array}{l}\text { No of } \\
\text { the } \\
\text { experim } \\
\text { ent }\end{array}$} & \multirow{3}{*}{ Tire } & \multicolumn{4}{|c|}{$\begin{array}{l}\text { Headlamp intensity along the optical } \\
\text { headlamp axis, } \mathrm{Cd}\end{array}$} \\
\hline & & \multicolumn{2}{|c|}{ Right headlamp } & \multicolumn{2}{|c|}{ Left headlamp } \\
\hline & & $\begin{array}{l}\text { Low } \\
\text { beam }\end{array}$ & $\begin{array}{l}\text { High } \\
\text { beam }\end{array}$ & $\begin{array}{l}\text { Low } \\
\text { beam }\end{array}$ & $\begin{array}{l}\text { High } \\
\text { beam }\end{array}$ \\
\hline $\begin{array}{c}1 \\
\text { (clean } \\
\text { screen) }\end{array}$ & \multirow{4}{*}{$\begin{array}{l}\text { class } \\
\mathrm{N} \text { of } \\
\text { high } \\
\text { and } \\
\text { low } \\
\text { beam }\end{array}$} & $\begin{array}{c}\text { Upper } \\
\text { limit- } \\
460 \\
\text { Lower } \\
\text { limit- } \\
7950\end{array}$ & 28500 & $\begin{array}{c}\text { Upper } \\
\text { limit - } \\
470 \\
\text { Lower } \\
\text { limit - } \\
7750\end{array}$ & 13400 \\
\hline $\begin{array}{c}2 \\
\text { (after } \\
\text { the first } \\
\text { set of } \\
\text { test } \\
\text { runs) }\end{array}$ & & $\begin{array}{l}\text { Upper } \\
\text { limit - } \\
520 \\
\text { Lower } \\
\text { limit - } \\
6531\end{array}$ & 17700 & $\begin{array}{c}\text { Upper } \\
\text { limit - } \\
360 \\
\text { Lower } \\
\text { limit - } \\
6500\end{array}$ & 9200 \\
\hline $\begin{array}{c}3 \\
\text { (after } \\
\text { the } \\
\text { second } \\
\text { set of } \\
\text { test } \\
\text { runs) }\end{array}$ & & $\begin{array}{l}\text { Upper } \\
\text { limit - } \\
548 \\
\text { Lower } \\
\text { limit - } \\
4771\end{array}$ & 8132 & $\begin{array}{c}\text { Upper } \\
\text { limit - } \\
878 \\
\text { Lower } \\
\text { limit - } \\
4718\end{array}$ & 5033 \\
\hline $\begin{array}{c}4 \\
\text { (after } \\
\text { the third } \\
\text { set of } \\
\text { test } \\
\text { runs) }\end{array}$ & & $\begin{array}{l}\text { Upper } \\
\text { limit - } \\
356 \\
\text { Lower } \\
\text { limit - } \\
700\end{array}$ & 1800 & $\begin{array}{c}\text { Upper } \\
\text { limit - } \\
200 \\
\text { Lower } \\
\text { limit - } \\
334\end{array}$ & 465 \\
\hline
\end{tabular}

The number of headlamp intensity control experiments was determined based on the number of test runs for studying external lights contamination by deicing agents.

The experiment results in Table 3 were processed in Microsoft Excel and graphs were constructed.

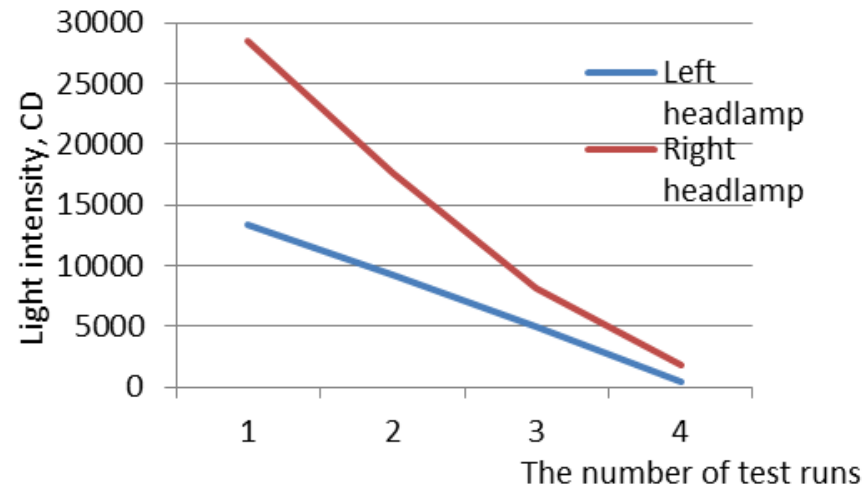

Fig. 8. Light intensity curve for high beam headlamps contaminated by deicing agents 


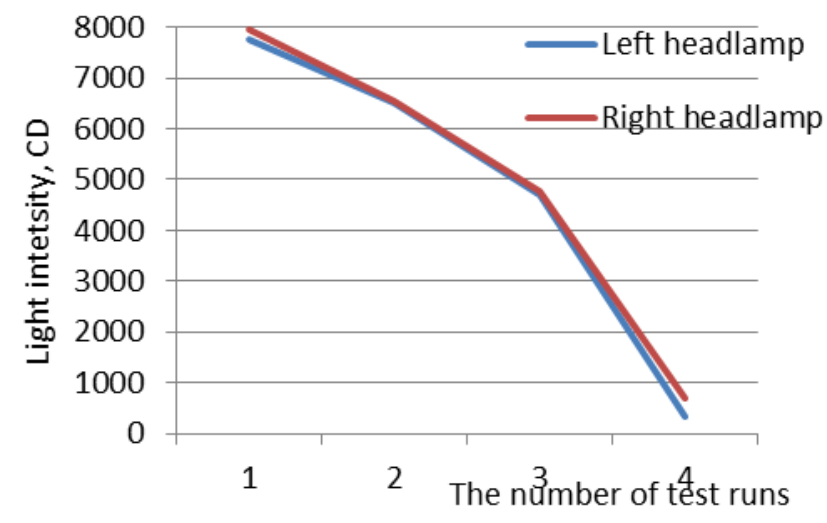

Fig. 9. Light intensity curve for low beam headlamps contaminated by deicing agents

The results were used to create light intensity-light transmission curves for left and right high beam headlamps (Fig. 10).

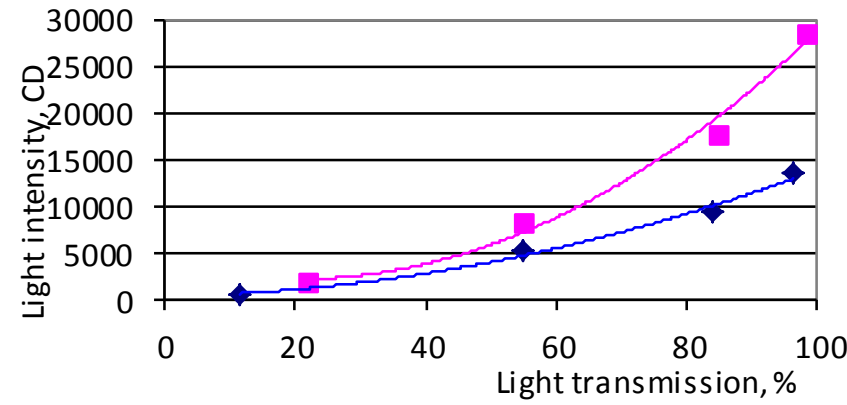

Fig.10. Light intensity - light transmission curves for contaminated high beam headlamps: The curve for the right headlamp is light, the curve for the left headlamp is dark; and - experiment; — and - calculation.

Based on the experiment results, the light intensity - light transmission curves for the contaminated right high beam headlamp were constructed:

$$
I_{h}=4,1548 \cdot T_{h i}^{2}-166,87 \cdot T_{h i}+3748
$$

where $I_{h}-$ light intensity for the right headlamp;

$T_{h i}$ - light transmission of the right headlamp screen glass.

The approximation reliability coefficient was $R^{2}=0,9869$.

The mathematical relationship between the left headlamp intensity and light transmission of the contaminated screen of the left headlamp is

$$
I_{h}=1,2356 \cdot T_{h i}^{2}+11,857 \cdot T_{h i}+243,68
$$

The approximation reliability coefficient was $R^{2}=0,9887$.
The light intensity - light transmission curves for contaminated screens of the low beam headlamps were constructed.

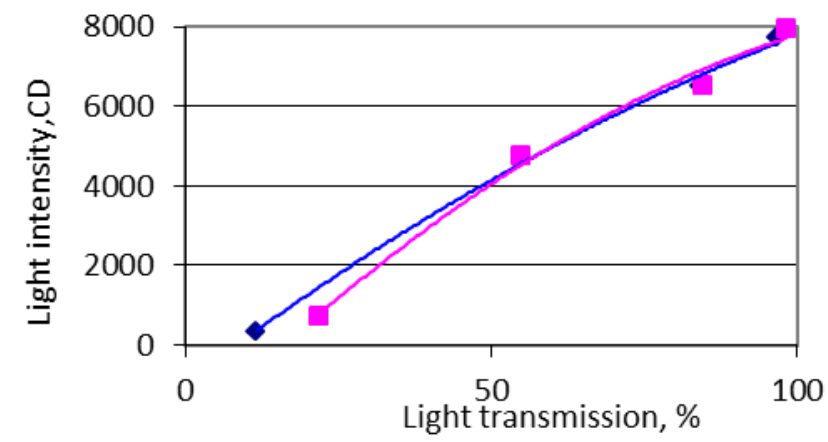

Fig. 11. The light intensity - light transmission curves for contaminated screens of the low beam headlamps: the curve for the right headlamp is light, the curve for the left headlamp is dark; and - experiment; $\_$and —— calculation

The functional relationship between the light intensity and the light transmission of the right headlamp is as follows:

$$
I_{h}=-0,5317 \cdot T_{h i}^{2}+154,71 \cdot T_{h i}+2354
$$

The approximation reliability coefficient was $R^{2}=0.9903$.

The functional relationship between the light intensity and the light transmission of the left headlamp was identified:

$$
I_{h}=-0,2898 \cdot T_{h i}^{2}+116,11 \cdot T_{h i}-934,86
$$

The approximation reliability coefficient was $R^{2}=0.9958$.

\section{CONCLUSIONS}

The experiment results were used to identify the effects of external headlamp contamination by deicing agents on light intensity.

The experiments proved that in wintertime, deicing chemicals can decrease low and high beam headlamp intensity $11,3-23,2$ times and 15,8-28,8 times respectively which is dangerous at a low tire-road grip coefficient.

The analysis of road visibility in winter night time under poor illumination due to headlamps contamination can be a venue for further research.

\section{References}

[1] IRGM Road winter slipperiness guidance. Ministry of transport of the RF, 2003; http://infosait.ru/norma_doc/41/41133/index.htm

[2] IRGM Deicing materials requirements. Moscow, Infromavtodor, p. 72 2003.

[3] Road safety data [Electronic resource] URL: http://stat.gibdd.ru/ (07.09.2017).

[4] Government of Irkutsk oblast. Official website http://irkobl.ru/sites/gkh/transport/BDD/?type=special

[5] A.I. Fedotov, S.M.Gergenov, Z.V. Darkhanov "A tire tester for experimental studies of automobile tire properties when moving on 
roads covered with deicing chemicals" In: Wheeled vehicle safety under operation conditions. Proceedings of the 99th International Scientific and Technical Conference of INRTU; , pp. 150-159, 2017.

[6] S.M. Gergenov V.A. Korchagin, Darkhanov Z.V. "Studies on grip tire properties“ Polzunov yearbook, vol. 2, p. 91-95, 2015.

[7] D.R. Abelkhanova "Improvement of efficiency of deicing agents application on automobile roads" $\mathrm{PhD}$ Thesis in Engineering Sciences: 05.23.11, MARI, Moscow, p.169, 2011.

[8] P.A. Kim, "Improvement of pedestrian safety of zebra crosswalks" PhD Thesis in Engineering Sciences: 05.22.10 ISTU, Irkutsk. p. 149, 2014 .
[9] E.A. Syutova, N.M. Alykov "Comparative tests of new deicing agents» ASU. Ecology and industry of Russia, vol. 2, pp. 47-51, 2012.

[10] Federal Law No 131-FZ “On general principles of local government management in Russia“" of October 6, 2003.

[11] Technical Regulations of the Customs Union CU TR018/2011 on wheeled vehicles safety. Moscow, 2011

[12] Research and production company META Light transmission gage TONIK. Manual M 019.000.00 MM. 